$\begin{array}{lllllllllll}S & E & M & \text { I } & \text { N } & \text { G } & \mathbb{R} & \mathbb{R} & 0 & 0 & M\end{array}$

\title{
米の澱粉粒のライブ観察 複粒形成の仕組みが見えてきた
}

\section{川越 靖}

\section{農業生物資源研究所}

\section{はじめに}

日常生活で身近な物質の澱粉については, このセミ ナー室の連載でも明らかなように, 生合成と分解, 物 性，産業利用など幅広い分野で活発な研究活動の歴史が ある．今後も新たな発見や産業利用における発明は続く と予想される，ところが意外なことに，澱粉生合成の場 である細胞内小器官（オルガネラ）のアミロプラストは これまであまり研究対象になっていない。そのため, ア ミロプラストの構造や分裂・発達の様式は不明な点が多 い.この理由として，アミロプラストは単離・精製する ことが難しい，葉緑素を含まないため蛍光顕微鏡での観 察が難しい，また葉緑体と同じ類のプラスチドとして認 識されていたことなどが挙げられる。一方, 観察が難し いとされていたオルガネラについて，共焦点レーザー顕 微鏡と蛍光タンパク質の開発により詳細な観察が容易に なった。イネは組換え体を作りやすいため, 肧乳細胞の アミロプラストも蛍光タンパク質を利用してライブ観察 (生きた細胞の観察) が可能になった。 その結果, アミ ロプラストの分裂様式や内部構造の詳細が明らかになっ ただけでなく，澱粉粒合成の仕組みについても全く予期 していなかった研究成果が得られつつある。このセミ ナー室では, アミロプラストのライブ観察から見えてき た複粒型の澱粉形成の仕組みを紹介する.

\section{複粒型澱粉とは？}

米の重さの約 8 割は澱粉粒からなる，米に含まれる澱 粉粒はその名称から想像される丸いものとは異なり, 水 を砕いたときにできるような角があり，一部のみに丸み のあるものが多い。このような角のある澱粉粒が 2 個か ら数十個，隙間なく集まって，全体として球状の塊（集 合体）になる．玄米を中心で割って，その断面を走査型 電子顕微鏡で観察すると，アミロプラストの表面に沿っ て割れたものと，アミロプラスト内部で割れたものが認 識できる（図1)。アミロプラスト内部で割れたもので は澱粉粒が隙間なく配置している。このような形態の澱

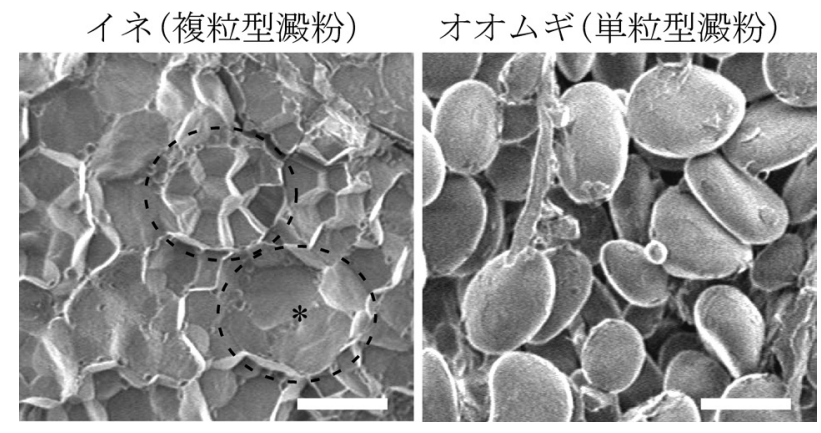

図1ロイネ（品種 日本晴）とオオムギ（品種 すずかぜ）の完 熟種子の断面を走査型電子顕微鏡で観察

イネのアミロプラストで, その内部で割れたものを破線のみ, 表 面に沿って割れたものを破線と*で示す. $\mathrm{Bar}=10 \mu \mathrm{m}$. 
粉粒を複粒型澱粉（compound type）と呼ぶ.一一方，卜 ウモロコシや麦類の胚乳では一つのアミロプラストに球 形やレンズ状の一つの澱粉粒が形成され，これらを単粒 型澱粉 (simple type) と呼ぶ. オオムギの種子を同様に して割った断面には, レンズ状の澱粉粒が多く, 澱粉粒 間の隙間が大きい（図1)。ジャガイモの澱粉も単粒型 である。

イネ科植物の種間における澱粉粒の形態比較から，イ ネ科の祖先種は複粒型澱粉を形成していたと推察され る ${ }^{(1)}$. トゥモロコシや麦類で単粒型澱粉が合成されるよ うになった変異の実態は不明である。興味深いことに, トウモロコシでは脂質合成に関与するモノガラクトシル ジアシルグリセロール合成醅素（MGD1）欠損変異体が 複粒型澱粉と形態的に似た澱粉粒を合成する ${ }^{(2)}$.ところ が，単粒型澱粉を合成するイネの変異はいまだ報告され ていない。

\section{イネ胚乳のアミロプラストの可視化}

アミロプラストを可視化するためには遺伝子組換え (形質転換) 技術が必須である.イネの一般的な形質転 換法では, 種子の肧盤組織由来のカルスとアグロバクテ リウムとを共存培養して, バイナリーベクターと呼ばれ るプラスミドにコードされた目的遺伝子をカルスの核ゲ ノムに導入する．形質転換したカルスを抗生物質などで 選抜し，適当な植物ホルモンを加えて植物体を再分化さ せる．緑色や赤色の蛍光タンパク質とアミロプラストに 局在するタンパク質との融合遺伝子を作製し, 登熟種子 の肧乳細胞でそれらの遺伝子を働かせると，蛍光を手が かりにアミロプラストのライブ観察が可能になる。融合
遺伝子の作製に用いられたイネのタンパク質は，アミロ プラストの分裂に関与するタンパク質（FtsZ1, FtsZ2-1, ARC5, MinD, MinE), 澱粉代謝関連酵素（SSI, SSIVb, GBSSI, ISA3), 外包膜タンパク質 (OEP7), 内包膜タン パク質（BT1）などである ${ }^{(3)}$. 共焦点レーザー顕微鏡の 利点は蛍光タンパク質を発現する生の組織・細胞の観察 が容易なことである．種子の生切片の作製では，開花後 7 日目ごろまでの登熟初期の組織はまだ柔らかく液状の ため不向きである。これに対し, 開花後 1 週間から 3 週 間は適当な硬さで，切片作製が容易である。この時期の 種子の中心部を輪切りにすると, 糊粉層の内側に隣接す る数層の細胞 (subaleurone) で発達するアミロプラス トのみ観察可能である。これらの細胞のさらに内側の細 胞, つまり種子の中心部に含まれるアミロプラストは, これまで試された融合タンパク質では観察できていな い. 中心部の蛍光が弱い理由は不明であるが, 中心部の 細胞の澱粉合成は開花後 1 週間後までにほぼ終了し，ア ミロプラストの包膜は一部崩壊し，アミロプラストに局 在する融合夕ンパク質の多くは分解される可能性が高 い.

\section{アミロプラストの内部構造}

アミロプラストや葉緑体などのプラスチドのストロマ で機能するタンパク質の多くは核ゲノムにコードされた 遺伝子産物で, 細胞質で翻訳された後にプラスチドに輸 送される ${ }^{(4)}$. 核コードのストロマタンパク質が二重膜に 包まれたプラスチドのストロマに輸送される経路には少 なくとも2つある。一つは, 外包膜 $(\mathrm{OEM})$ と内包膜 （IEM）にそれぞれ存在するTocと Ticと呼ばれる夕ン

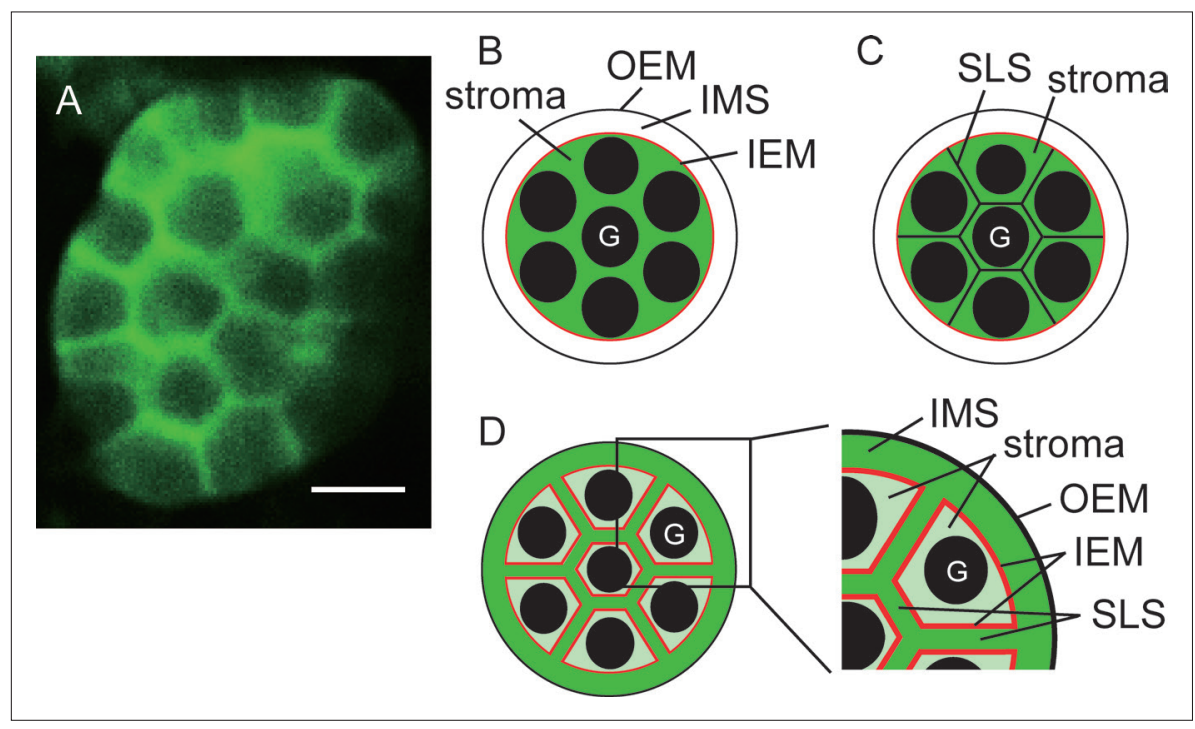

図2・アミロプラストの内部構造モ デル

（A）イネ（品種 日本晴）の肧乳細胞 のアミロプラストを $\mathrm{tp}^{\mathrm{GBSSI}} \mathrm{GFP}$ 用 いて共焦点レーザー顕微鏡で観察. $\mathrm{Bar}=3 \mu \mathrm{m} . \quad$ （B）連続したストロマ で複数の澱粉粒が合成される。(C, D）ストロマはSLSで仕切られ，仕切 られた各ストロマで澱粉粒が独立し て発達する. GFPの局在は, (C) で は主にストロマであるのに対し，(D) ではストロマよりもSLSとIMSに局 在する. G (starch granule); OEM (outer envelope membrane); IEM (inner envelope membrane); IMS (inter membrane space); SLS (septum-like structure). 
パク質複合体を通過してストロマに輸送される経路であ る. Tocと Ticを通過するタンパク質は， N末端に数十 アミノ酸残基からなるトランジットペプチドを含み, Ticを通過する際にトランジットペプチドはストロマで 切断される. 2 つ目の経路は小胞体の内腔から小胞輸送 によってゴルジ体経由でプラスチドのストロマに輸送さ れる経路である．分泌タンパク質の $\alpha$-アミラーゼは細 胞壁に加えて葉緑体にも局在するタンパク質の一つであ $3^{(5)}$.

完熟種子から精製したアミロース合成酵素（Granulebound starch synthase; GBSSI) の N末端は78番目のア ラニン残基である ${ }^{(6)}$.このことは, 1 番目から 77 番目ま でのアミノ酸残基からなるペプチドがトランジットペプ チドとして機能することを示唆する. 実際, GBSSIのト ランジットペプチド $\left(\mathrm{tp}^{\mathrm{GBSSI}}\right)$ を緑色蛍光タンパク質 (GFP) の N末端に付加した $\mathrm{tp}^{\mathrm{GBSSI}} \mathrm{GFP}$ を肧乳で発現さ せると, GFPはアミロプラストにターゲットされる. その結果, GFPの蛍光を手がかりにアミロプラストの ライブ観察が可能になる（図2A）。このような手法を 使ったイネの胚乳のアミロプラストの観察は約 10 年に なるが, その間, 得られた画像の解釈は二度修正するこ とになった。その経緯について背景を交えながら述べて みる。

\section{アミロプラスト内部構造モデル(1)}

澱粉粒はアミロプラストのストロマで合成され，アミ ロペクチンの結晶性の構造を含む。そのため, 澱粉粒の 内部にはGFPなどの大きな分子が自由に入り达むス ペースはないと推察した. GFPがアミロプラストのス トロマに取り込まれると, 澱粉粒はGFPが存在しない 暗い部分として現れると推察した。すなわち，澱粉粒を GFPの蛍光で直接観察するのではなく, 澱粉粒を合成 する場のストロマを観察することで，間接的に澱粉粒の 観察が可能になると推察した。この解釈と矛盾しない次 のような結果が得られた。澱粉粒の代わりに水溶性のグ リコーゲンを合成するシュガリー変異体のアミロプラス トでは, GFPはストロマ全体に分散し，蛍光を発しな い黒く抜けた塊は存在しない $(7)$.これらの結果を基にし て作製したアミロプラストの内部構造のモデルを図2B に示す。

\section{アミロプラスト内部構造モデル(2)}

プラスチドの起源である藍藻（シアノバクテリア）の
細胞分裂では, 細胞の中心部の分裂面に FtsZタンパク 質が重合したリングが形成され，そのリングが徐々に縮 まりながら細胞分裂が進行する。このような分裂様式は 2分裂（binary fission）と呼ばれる。同様に葉緑体の分 裂様式も 2 分裂である ${ }^{(8)}$. ところが，分裂中のアミロプ ラストを観察したところ，小さなアミロプラストが数珠 状に繋がった様子や，比較的大きなアミロプラストの表 面に小さなアミロプラストが複数個所で出芽しているよ うなものが観察された。これらの結果は, アミロプラス トの分裂様式は複数個所で同時進行的に分裂する多分裂 であることを示す ${ }^{(9)}$.

興味深いことに，葉緑体の分裂に関与するタンパク質 の過剩発現や発現抑制はアミロプラストの分裂を阻害す るだけでなく，澱粉粒の形状にも変化をもたらす ${ }^{(10)}$. さらに驚くことに, 内包膜の膜タンパク質 Brittle1 （BT1）とGFPの融合タンパク質は，アミロプラスト全 体を包む内包膜に加えて，アミロプラスト内部の澱粉粒 の間にも検出された。すなわち，澱粉粒の間に内包膜に 似た膜構造が存在することが示唆された。これらの結果 をもとに，藍藻の細胞分裂で形成される隔壁に類似した 構造（septum-like structure; SLS）が澱粉粒の間に形成 されると提唱された ${ }^{(10)}$. その提唱されたモデルでの $\mathrm{tp}^{\mathrm{GBSSI}} \mathrm{GFP}$ の局在を模式的に図 $2 \mathrm{C} に$ 示す.1番目のモ デル（図2B）との違いは, アミロプラストのストロマ がSLSで仕切られていることである.

\section{アミロプラスト内部構造モデル (3)}

GFP と赤色蛍光タンパク質の 1 種Cherry を併用する と, 2 色の蛍光タンパク質の同時観察が可能になる. そ こで, 澱粉合成酵素SSI と GFP との融合タンパク質 (SSI-GFP) と, tp ${ }^{\mathrm{GBSSI}}$ をCherryの $\mathrm{N}$ 末端に付加した $\mathrm{tp}^{\mathrm{GBSS}}$ Cherry とを同時に発現する形質転換イネを作製 してアミロプラストを観察した. tp ${ }^{\mathrm{GBSSI}}$ Cherry は予想 どおり，図 $2 \mathrm{~A}$ に示す $\mathrm{tp}^{\mathrm{GBSSI}} \mathrm{GFP}$ と同様な局在を示し

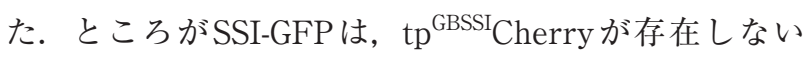
暗い部位，すなわち澱粉粒での局在を示した（未発表 データ)。つまり, 両タンパク質はアミロプラストの内 部で異なる局在を示したのである。この予想外の結果

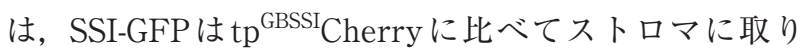
込まれる効率が極めて高いことを示唆する。それと同時 に, $\mathrm{tp}^{\mathrm{GBSSI}}$ Cherryの主な局在は, これまで想定してい たストロマよりも，むしろ OEM とIEMの間の領域（inter-membrane space;IMS）とIEMに挟まれたSLSであ ることが示唆された．この解釈を図 $2 \mathrm{D} に$ 模式的に示 
す.

$\mathrm{tp}^{\mathrm{GBSS}}$ を $\mathrm{N}$ 末端に付加した蛍光タンパク質を手がか りにしたアミロプラストの観察を続ける過程で, 内部構 造についてのモデルは 2 度修正することになった．今後 新たなデータが得られれば，現在のモデルも修正される 可能性は十分にある。内部構造のモデルの修正と関連し て,アミロプラストと葉緑体との違いについて詳細な比 較解析が必要である。たとえば，トランジットペプチド を切断するぺプチダーゼの局在比較である. 葉緑体の久 トロマ局在のタンパク質のトランジットペプチドは，ス トロマに局在するペプチダーゼによって切断される。一 方，アミロプラストでは $\mathrm{tp}^{\mathrm{GBSSI}}$ による蛍光タンパク質 のストロマへの輸送効率が悪いことから，トランジット ペプチドを切断するペプチダーゼがストロマに加えて IMS とSLSにも存在する可能性が示唆される. $\mathrm{tp}^{\mathrm{GBSSI}}$ はアミロプラストのどこで切断されるか，という問題は 今後の研究課題の一つである.

10 年間のアミロプラストのライブ観察から得られた 要点は, 融合夕ンパク質の種類が増えるにつれて内部構 造の情報も増えてきたことである。また，先入観にとら われない粘り強い観察が肝要であることは, 強調してし 過ぎることはない.

\section{複粒型港粉はどうやってできる ?}

イネに特徵的な複粒型澱粉は 2 個から数十個の角のあ る澱粉粒が隙間なく集まった集合体である(図1)。こ こで，2個の澱粉粒を含むアミロプラストはどのように
できるか思考してみる。一つ目のモデルを模式的に図 3Aに示す。まず，アミロプラストの赤道面で澱粉粒が 分解される. その赤道面にSLSが形成され, SLSで仕切 られた $2 つ の$ 澱粉粒ができる。これに対して，2つ目の モデルでは（図3B），澱粉粒は分解されず，ストロマ内 にSLSが形成され，ストロマは不均等に分割される，新 たに生じたストロマで澱粉粒の合成が開始され，2個の 澱粉粒がそれぞれ発達して，2個の澱粉粒を含むアミロ プラストになる。これまでの観察で, 澱粉粒が赤道面で 分解される様子は観察されていない。一方，アミロプラ ストの表面で円盤状のシートは多数観察されている ${ }^{(10)}$. このような円盤状のシートは合成されつつあるSLSの 可能性があり，後者のモデル（図3B）と矛盾しない.

それでは次に，数十個の澱粉粒を含むアミロプラスト はどのようにできるか思考してみる。まず，すでに多数 の澱粉粒を含むアミロプラストを想定する（図3C）。そ のアミロプラストの表面に面したストロマで, 円盤状の SLSが複数個所で同時進行的に形成される。すると，新 たにできたSLSと同じ数のストロマがアミロプラスト の最外層に生じる．各ストロマで澱粉粒の合成が新たに 開始され，アミロプラストの最外層で澱粉粒の数が増加 する.このようして澱粉粒の数を増やすと無制限に増え ることができる，細胞内では，ほかのアミロプラストや オルガネラと接触することで最終的な澱粉粒の数が決ま ると推察される.

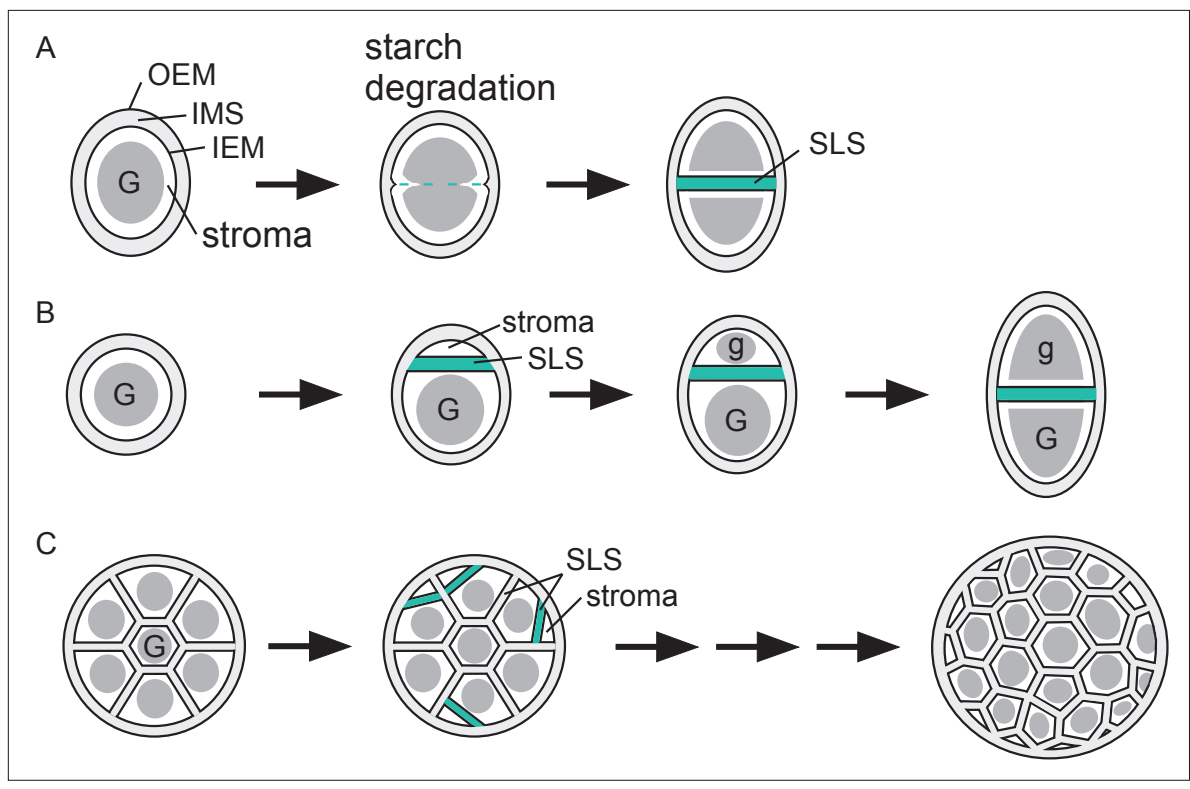

図 3 日 複粒型澱粉の形成機構モデル (A，B）澱粉粒が1個から2個に増え る場合.（A）澱粉粒が中心部（赤道 面）で分解され，分解された赤道面 にSLSが形成される。（B）アミロプ ラストの表面に近いストロマでSLS が合成され，ストロマは不均等に分 割される。澱粉粒を含まないストロ マで2個目の澱粉粒 $(\mathrm{g})$ の合成が開 始され, Gと $\mathrm{g}$ の2個の澱粉粒がそれ ぞれ独立に発達する. (C) 多数の澱 粉粒を含むアミロプラストでさらに 澱粉粒が増える場合.アミロプラス トの表面に面したストロマで, 複数 個所でSLS (緑線) が形成される. その結果, 澱粉粒を含まないストロ マが生じ，それらのストロマで澱粉 粒の合成が新たに開始され発達する. 結果として，アミロプラストの最外 層で澱粉粒の数が増える. 


\section{多角形の港粉粒はどうやってできる ?}

最後に，多角形の澱粉粒はどのようにできるかを思考 してみる。澱粉粒の発達は, その表面や内部で, 一群の 酵素タンパク質がグルカン鎖の伸長，枝付け，枝切り反 応を協調して進めることに依存する。これらの合成反応 は各酵素が結合したグルカン鎖で独立に進むと推察され るため, 多くの酵素反応の制御のみで最終的に多角形の 澱粉粒ができあがることは想像しがたい，そのため，澱 粉粒の形を決める仕組みは, 醰素反応とは別のところに もあると考えられる。

そこでまず，ストロマにSLSによる仕切りがない場 合を想定してみる (図2B)。この場合, 連続したストロ マで多数の澱粉粒が同時に合成されることになる．隣接 する澱粉粒との間でグルカン鎖が絡み合わない理由や, 澱粉粒間の境界が最終的に平面になる仕組みを思い浮か べることは難しい.

では，ストロマがSLSによって仕切られているとど うだろう (図2D)。この場合には, 仕切られたストロマ を充填するように澱粉粒が合成されると角のある澱粉粒 の合成は可能になる。言い換えると, SLSによる仕切り が鋳型となり，仕切られたストロマで，澱粉が空間的に 可能な限り合成されれば, 結果的に澱粉粒は鋳型と同じ 形になる ${ }^{(3)}$.

\section{おわりに}

数十個の澱粉粒からなる複粒型澱粉ができる仕組み と, 角のある澱粉粒が合成される仕組みは密接に関連し ていることを述べてきた，すなわち，SLSによって仕切 られたストロマを想定すると, 最初は関連が薄いように 思える2つの仕組みは，実は表裏一体であることが見え てくる．蛍光タンパク質を手がかりにしたアミロプラス トのライブ観察の結果は, SLSで仕切られたストロマの 存在を強く支持する. しかしながら, SLSの構造や形成 に関与する酵素などは不明である。ここで特筆されるこ とは, 秋田県立大学の藤田直子らによって SLSの構造 変化を伴った変異体が最近発見されたことである。この 変異体は澱粉合成酵素のSSIIIa とSSIVbの機能欠損型 二重変異体である。驚くことに，この二重変異体では球
形の澱粉粒が合成される(11)。その理由としては, SLS の鋳型としての機能の低下を考えることができる，今 後, アミロプラストの内部構造を切り口にした澱粉研究 の新たな展開が期待される.

謝辞 : 本稿で紹介した内容の一部は新技術・新分野創出のための基礎研 究推進事業「イネ肧乳細胞のオルガネラ工学の開発と利用」の研究成果 を含みます。川東広幸博士に大麦種子の提供を感謝します。若佐雄也博 士に貴重なコメントを感謝します。

\section{文献}

1) R. Matsushima, J. Yamashita, S. Kariyama, T. Enomoto \& W. Sakamoto: J. Appl. Glycosci., 60, 37 (2013).

2) A. M. Myers, M. G. James, Q. H. Lin, G. Yi, P. S. Stinard, T. A. Hennen-Bierwagen \& P. W. Becraft: Plant Cell, 23, 2331 (2011).

3) Y. Kawagoe :J. Appl. Glycosci., 60, 29 (2013).

4) K. Cline \& C. Dabney-Smith:Curr. Opin. Plant Biol., 11, 585 (2008).

5) A. Kitajima, S. Asatsuma, H. Okada, Y. Hamada, K. Kaneko, Y. Nanjo, Y. Kawagoe, K. Toyooka, K. Matsuoka, M. Takeuchi et al. : Plant Cell, 21, 2844 (2009).

6) T. Taira, N. Fujita, K. Takaoka, M. Uematsu, A. Wadano, S. Kozaki \& S. Okabe : Biochem. Genet., 33, 269 (1995).

7) Y. Kawagoe, A. Kubo, H. Satoh, F. Takaiwa \& Y. Nakamura : Plant J., 42, 164 (2005).

8) S. Miyagishima: Plant Physiol., 155, 1533 (2011).

9) M. S. Yun \& Y. Kawagoe: Plant Cell Physiol., 50, 1617 (2009).

10) M. S. Yun \& Y. Kawagoe: Plant Cell Physiol., 51, 1469 (2010).

11）藤田直子：化学と生物, 51, 400 (2013).

\section{プロフィル}

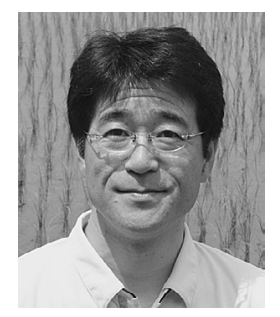

川越 靖 (Yasushi KAWAGOE)

$<$ 略歴 $>1987$ 年北海道大学農学部農 業生物学科卒業 $/ 1989$ 年同大学大学院 修士課程修了/1994年Louisiana State University, Ph.D. / 1995年 The Hebrew University of Jerusalem, Golda Meir Research Fellow / 1997 年科学技術振興事 業団長期海外在外若手研究員 (University of California, Davis) / 2000年農業生物資 源研究所研究官 $/ 2001$ 年農業生物資源研 究所主任研究員 $/ 2007$ 年名古屋大学大学 院生命農学研究科客員教授 (兼任) <研究 テーマと抱負>コメのタンパク質と澱粉 の基礎研究, 米粉用イネの育種開発など. 「基礎研究の成果を食卓に届ける」を合言 葉に顕微鏡室や田んほに出ていますく趣 味>息子の野球の試合観戦 